\title{
The Journal of Antibiotics
}

The Japan Antibiotics Research Association (JARA) and NPG do not currently have publishing rights for this article. We are attempting to contact the author(s) to obtain a License to Publish for this article. If you are an author of this article please contact the Publishing Manager at ja@natureasia.com

日本抗生物質学術協会およびNature Publishing Groupは現在この論文フルテキストのオ ンライン出版の権利を保有しておりません。本論文著者からの出版同意書の提出を待って 公開の予定です。本論文の著者は、本件担当者まで電子メールにてご連絡をお願い申し上

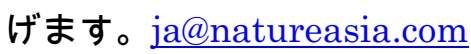

